Article

\title{
Lead Contamination in Selected Foods from Riyadh City Market and Estimation of the Daily Intake
}

\section{Zeid A. Al Othman}

Department of Chemistry, College of Science, King Saud University, Riyadh 11451, Saudi Arabia; E-Mail: zaothman@ksu.edu.sa; Tel.: +96614675999, Fax: +96614675992

Received: 29 August 2010; in revised form: 7 October 2010 / Accepted: 11 October 2010 /

Published: 25 October 2010

\begin{abstract}
This study was carried out to determine lead contamination in 104 of the representative food items in the Saudi diet and to estimate the dietary lead intake of Saudi Arabians. Three samples of each selected food items were purchased from the local markets of Riyadh city, the capital of Saudi Arabia. Each pooled sample was analyzed in triplicate by ICP-AES after thorough homogenization. Sweets $(0.011-0.199 \mu \mathrm{g} / \mathrm{g})$, vegetables $(0.002-0.195 \mu \mathrm{g} / \mathrm{g})$, legumes $(0.014-0.094 \mu \mathrm{g} / \mathrm{g})$, eggs $(0.079 \mu \mathrm{g} / \mathrm{g})$, meat and meat products $(0.013-0.068 \mu \mathrm{g} / \mathrm{g})$ were the richest sources of lead. Considering the amounts of each food consumed, the major food sources of lead intake for Saudi can be arranged as follows: vegetables $(25.4 \%)$, cereal and cereal products $(24.2 \%)$, beverages $(9.7 \%)$ sweets $(8.2 \%)$, legumes $(7.4 \%)$, fruits $(5.4 \%)$ milk and milk products $(5.1 \%)$. The daily intake of lead was calculated taking into account the concentration of this element in the edible part of the daily consumption data which were derived from two sources, (a) the KSA food sheet provided by the Food and Agriculture Organization (FAO) and (b) from questionnaires distributed among 300 families in Riyadh city. The results showed that the daily intakes of lead according to the two sources are 22.7 and $24.5 \mu \mathrm{g} /$ person/day respectively, which are lower than that mentioned by The Joint Expert Committee on Food Additives (JECFA), whereas it is comprabale with that of other countries.
\end{abstract}

Key words: lead contamination; food basket samples; lead daily intake 


\section{Introduction}

Lead is a toxic metal that can be found everywhere in the environment. Overexposure to lead continues to be an important worldwide problem [1]. Food is an important source of lead and determination of lead in food can be used for the estimation of lead exposure [2]. The level of lead in the Earth's crust is about $20 \mu \mathrm{g} / \mathrm{g}$. The Industrial Revolution gave rise to an increase in the amount of lead in the environment and an even bigger increase occurred around 1920 when leaded gasoline was introduced. Leaded gasoline is still not banned everywhere in the World, and it still used in the developed countries. In areas where leaded gasoline is banned, the major exposure pathways of nonsmoking adults are from food and water. Several studies were done to determine the concentration of lead in foods [3-5] and to study its dangerous effects. Recently, the USA, all European countries and many developing countries have outlawed or strictly regulated the use of leaded petrol. In such countries, levels of lead in food and drinking water are closely monitored. Lead may reach and contaminate plants, vegetables, fruits and canned food through air, water and soil during cultivation [5-7] and also during industrial processing and packaging [8]. Fruits and vegetables grown in polluted soils may become contaminated as a result of plant uptake of lead from soils or direct deposition of leaded dust onto plant surfaces $[9,10]$. Therefore, through these diverse mechanisms, lead deposited in soil becomes a persistent and long-term source of lead exposure for humans.

Lead exposure can occur through food, water, soil, air and the relative contributions from individual sources may depend on lifestyle and socioeconomic status. It was reported that the main sources of exposure for an adult are food (ranging from $0.4 \mu \mathrm{g} / \mathrm{kg}$ bw/week to $10.1 \mu \mathrm{g} / \mathrm{kg}$ bw/week) and water (ranging from $0.23 \mu \mathrm{g} / \mathrm{kg}$ bw/week to $0.35 \mu \mathrm{g} / \mathrm{kg}$ bw/week). The main potential sources of exposure to lead in children are food, air, water and dust or soil. It has been reported that the dietary intakes of children (ranging from $0.6-30 \mu \mathrm{g} / \mathrm{kg} \mathrm{bw} /$ week) could be two to three times that of adults. In other dietary exposures studies such as those conducted in the UK and mainland China, cereals and vegetables were found to be the main dietary sources of lead, which contributed $31 \%$ to $40 \%$ of total dietary exposure for cereals, and $23 \%$ to $35 \%$ of total dietary exposure for vegetables $[11,12]$.

Watanabe et al. [13] reported that people, specially those who consume rice as a staple food for daily energy, are inevitably exposed to significant amount of lead via rice. Rice crops, even from nonpolluted areas, may be contaminated because of fertilizers that are used in forms containing lead. Amongst other foods fish are constantly exposed to lead from polluted water. Lead accumulates in their bodies tissues in different amounts depending on the size and age of fish [14-16]. Canned fish, especially canned tuna fish, is abundantly consumed because of its convenient and affordable use. In the same respect, several studies [17-19] have reported that the lead content in different type of chocolates varied between 0.07 and $4.0 \mu \mathrm{g} / \mathrm{g}$ product.

The United Nations World Health Organization (WHO) has also given recommendations for maximum lead content in food and water [20,21]. The Joint FAO/WHO Expert Committee on Food Additives (JECFA) [22] has established a provisional tolerable weekly intake (PTWI) of $25 \mu \mathrm{g} / \mathrm{kg}$ bw/ week for lead. PTWI is an estimate of the amount of a contaminant that can be ingested over a lifetime without appreciable risk. An intake above the PTWI does not automatically mean that health is at risk. Transient excursion above the PTWI would have no health consequences provided that the average intake over long period is not exceeded as the emphasis of PTWI is a lifetime exposure. Developing 
countries have been slow in putting in place regulatory restrictions on leaded products, and leaded petrol is still used in some cases. There is very little data on the magnitude of the contamination levels of lead in environment and in food in these countries.

Lead can be very harmful even at low concentrations when ingested over a long time [23-25]. After ingestion, the absorption rate of lead ranges from $3 \%$ to $80 \%$, whereas the typical absorption rates of dietary lead in adults and infants are $10 \%$ and $50 \%$, respectively. After absorption, lead is initially distributed to soft tissues throughout the body via blood, and then deposited in bone. Lead is excreted through the kidney and to a lesser extent in the bile while non-absorbed dietary lead is excreted in the feces. Organic lead may be metabolized to inorganic lead. The concentration of lead in blood is commonly used as a biomarker of exposure. Lead is a classical chronic toxic chemical. It may cause damages to kidneys, the cardiovascular, immune, hematopoietic, central nervous and reproductive systems. Short term exposure to high level of lead can cause gastrointestinal distress, anemia, encephalopathy and death [26]. The effect of exposure to lead varies according to dose and the age of the exposed person [27]. Manifestations of lead poisoning are nonspecific abdominal pain, constipation, irritability, myalgia, muscle aches, headache, anorexia, and decreased lipid concentrations. The Kingdom of Saudi Arabia (KSA) imports a lot of foodstuffs from several countries. These foods may be subjected to lead contamination as described above. The objective of this work was to estimate the levels of lead that may be present in some foods available in local markets in Riyadh city, to determine the food daily intake from the Food Consumption Survey (questionnaire) conducted in local population in Riyadh city 2010, and consequently the daily lead intake from food (questionnaire) and finally, to compare lead intake from the questionnaire with that from the food balance sheet of the KSA provided by the FAO.

\section{Results}

The data in Table 1 shows the measured lead content in various food items. The number of selected food items in each food group was as follows: cereals and cereal products $(n=9)$, legumes $(n=8)$, vegetables $(n=34)$, pickles $(n=2)$, fruits $(n=9)$, meats and meat products $(n=11)$, sweets $(n=10)$, eggs $(n=1)$, fat and oils $(n=4)$, beverages $(n=9)$. The highest lead content were found in sweets $(0.199$ $\mu \mathrm{g} / \mathrm{g}$ Snickers, $0.131 \mu \mathrm{g} / \mathrm{g}$ Triplex, $0.092 \mu \mathrm{g} / \mathrm{g}$ Twix, $0.083 \mu \mathrm{g} / \mathrm{g}$ Galaxy), $0.094 \mu \mathrm{g} / \mathrm{g}$ cowpeas, the medium concentration were found in egg $(0.074 \mu \mathrm{g} / \mathrm{g})$, chicken $(0.068 \mu \mathrm{g} / \mathrm{g})$, sardines $(0.063 \mu \mathrm{g} / \mathrm{g})$ while the lowest concentrations were found in bears and time $(0.002 \mu \mathrm{g} / \mathrm{g}$ of each) and potato $(0.003 \mu \mathrm{g} / \mathrm{g})$.

Table 1. Concentration of lead in analyzed food samples.

\begin{tabular}{lccc}
\hline Food kind & No & Sample & $\begin{array}{c}\text { Mean lead concentration } \\
(\boldsymbol{\mu g} / \mathbf{g} \text { dry weight food })\end{array}$ \\
\hline Vegetables & 1 & Cucumber & $0.016 \pm 0.009$ \\
& 2 & Zucchini & $0.013 \pm 0.011$ \\
& 3 & Green peas & $0.005 \pm 0.003$ \\
& 4 & Carrot & $0.027 \pm 0.015$ \\
5 & Potatoes & $0.003 \pm 0.001$ \\
& 6 & Eggplant & $0.024 \pm 0.019$ \\
7 & Green peppers & $0.012 \pm 0.0011$ \\
\hline
\end{tabular}


Table 1. Cont.

\begin{tabular}{|c|c|c|c|}
\hline & 8 & Okra & $0.025 \pm 0.021$ \\
\hline & 9 & Time & $0.002 \pm 0.001$ \\
\hline & 10 & Green hot pepper & $0.024 \pm 0.017$ \\
\hline & 11 & Sweet Potato & $0.013 \pm 0.06$ \\
\hline & 12 & Taro & $0.025 \pm 0.009$ \\
\hline & 13 & Onion & $0.015 \pm 0.011$ \\
\hline & 14 & Garlic & $0.012 \pm 0.002$ \\
\hline & 15 & Canned taro & $0.023 \pm 0.013$ \\
\hline & 16 & Canned green peas & $0.011 \pm 0.007$ \\
\hline & 17 & Canned carrots & $0.025 \pm 0.012$ \\
\hline & 18 & Canned okra & $0.038 \pm 0.016$ \\
\hline & 19 & Canned Spinach & $0.007 \pm 0.003$ \\
\hline & 20 & Canned Potato & $0.041 \pm 0.023$ \\
\hline & 21 & Canned jews mallow & $0.020 \pm 0.0016$ \\
\hline & 22 & Mallow & $0.014 \pm 0.009$ \\
\hline & 23 & Purslane & $0.004 \pm 0.002$ \\
\hline & 24 & Radish & $0.014 \pm 0.011$ \\
\hline & 25 & Dill & $0.027 \pm 0.015$ \\
\hline & 26 & Spinach & $0.015 \pm 0.008$ \\
\hline & 27 & Lettuce & $0.033 \pm 0.023$ \\
\hline & 28 & Round leafy lettuce & $0.195 \pm 0.065$ \\
\hline & 29 & Mint & $0.020 \pm 0.012$ \\
\hline & 30 & Coriander & $0.015 \pm 0.009$ \\
\hline & 31 & Cauliflower & $0.005 \pm 0.002$ \\
\hline & 32 & Watercress & $0.061 \pm 0.027$ \\
\hline & 33 & Cabbage & $0.027 \pm 0.008$ \\
\hline & 34 & Green onions & $0.027 \pm 0.009$ \\
\hline \multirow[t]{9}{*}{ Fruits } & 35 & Tomatoes & $0.025 \pm 0.017$ \\
\hline & 36 & Banana & $0.013 \pm 0.007$ \\
\hline & 37 & Strawberry & $0.017 \pm 0.009$ \\
\hline & 38 & Orange & $0.013 \pm 0.004$ \\
\hline & 39 & Pears & $0.002 \pm 0.001$ \\
\hline & 40 & Lemon & $0.014 \pm 0.003$ \\
\hline & 41 & Apple & $0.019 \pm 0.005$ \\
\hline & 42 & Canned strawberry & $0.030 \pm 0.011$ \\
\hline & 43 & Dried dates & $0.018 \pm 0.009$ \\
\hline \multirow[t]{2}{*}{ Pickles } & 44 & Pickled cucumber & $0.023 \pm 0.02$ \\
\hline & 45 & Pickled turnip & $0.027 \pm 0.018$ \\
\hline \multirow[t]{8}{*}{ Legume } & 46 & Green kidney Bean & $0.055 \pm 0.031$ \\
\hline & 47 & Canned green kidney beans & $0.047 \pm 0.025$ \\
\hline & 48 & Canned kidney beans & $0.018 \pm 0.009$ \\
\hline & 49 & Canned beans & $0.019 \pm 0.006$ \\
\hline & 50 & Canned beans & $0.031 \pm 0.015$ \\
\hline & 51 & Beans & $0.014 \pm 0.002$ \\
\hline & 52 & Canned peas & $0.048 \pm 0.029$ \\
\hline & 53 & Cowpeas & $0.094 \pm 0.033$ \\
\hline
\end{tabular}


Table 1. Cont.

\begin{tabular}{|c|c|c|c|}
\hline \multirow{9}{*}{$\begin{array}{c}\text { Cereal } \\
\text { and } \\
\text { cereal } \\
\text { products }\end{array}$} & 54 & Pasta & $0.047 \pm 0.013$ \\
\hline & 55 & Rice (Karos Snowight) & $0.032 \pm 0.021$ \\
\hline & 56 & Rice (Abu Sion) & $0.020 \pm 0.01$ \\
\hline & 57 & Bread & $0.015 \pm 0.009$ \\
\hline & 58 & White bread & $0.008 \pm 0.001$ \\
\hline & 59 & Biscuits (Tyoshob) & $0.025 \pm 0.015$ \\
\hline & 60 & Biscuits (Tyoshob strawberry) & $0.018 \pm 0.01$ \\
\hline & & Tea Biscuits & $0.036 \pm 0.022$ \\
\hline & 62 & Biscuits (Loucker)(Napolitaner) & $0.032 \pm 0.015$ \\
\hline \multirow{2}{*}{$\begin{array}{l}\text { Milk and } \\
\text { Milk }\end{array}$} & 63 & Fresh milk & $0.006 \pm 0.003$ \\
\hline & 64 & Danette banana-flavored milk & $0.018 \pm 0.008$ \\
\hline \multirow[t]{6}{*}{ Product } & 65 & Danette strawberry-flavored milk & $0.027 \pm 0.012$ \\
\hline & 66 & Yogurt & $0.025 \pm 0.01$ \\
\hline & 67 & Cheese & $0.003 \pm 0.001$ \\
\hline & 68 & Ice Cream (plastic tray) & $0.055 \pm 0.024$ \\
\hline & 69 & Ice Cream (paper package & $0.014 \pm 0.01$ \\
\hline & 70 & Vanilla ice cream (paper package) & $0.032 \pm 0.021$ \\
\hline \multirow[t]{9}{*}{ Beverages } & 71 & Orange and carrot juice & $0.016 \pm 0.011$ \\
\hline & 72 & Apple juice & $0.014 \pm 0.009$ \\
\hline & 73 & Fruit juice & $0.050 \pm 0.041$ \\
\hline & 74 & Orange juice & $0.010 \pm 0.009$ \\
\hline & 75 & Lemon juice & $0.053 \pm 0.026$ \\
\hline & 76 & Strawberry juice & $0.016 \pm 0.011$ \\
\hline & 77 & Lipton tea packages & $0.046 \pm 0.029$ \\
\hline & 78 & Lipton Tea & $0.065 \pm 0.033$ \\
\hline & 79 & Coffee & $0.053 \pm 0.041$ \\
\hline \multirow[t]{10}{*}{ Sweets } & 80 & Bounty & $0.051 \pm 0.034$ \\
\hline & 81 & Galaxy & $0.083 \pm 0.045$ \\
\hline & 82 & Snickers & $0.199 \pm 0.04$ \\
\hline & 83 & Vip & $0.066 \pm 0.019$ \\
\hline & 84 & Albeni & $0.021 \pm 0.008$ \\
\hline & 85 & Triplex & $0.131 \pm 0.004$ \\
\hline & 86 & Towers gold & $0.044 \pm 0.024$ \\
\hline & 87 & Twix & $0.092 \pm 0.032$ \\
\hline & 88 & Rush & $0.011 \pm 0.008$ \\
\hline & 89 & Halvah & $0.080 \pm 0.02$ \\
\hline \multirow{10}{*}{$\begin{array}{l}\text { Meat and } \\
\text { meat } \\
\text { products }\end{array}$} & 90 & Sardines Haakon hot & $0.050 \pm 0.01$ \\
\hline & 91 & Light meat tuna (Eldiafa) & $0.049 \pm 0.027$ \\
\hline & 92 & Light meat tuna (C Harvest) & $0.025 \pm 0.013$ \\
\hline & 93 & Cooked fish (Incheon Rural Slides) & $0.013 \pm 0.009$ \\
\hline & 94 & Light meat tuna (IFFCO) & $0.042 \pm 0.018$ \\
\hline & 95 & Light meat tuna (California) & $0.039 \pm 0.022$ \\
\hline & 96 & Sardines cooked (Milo) & $0.063 \pm 0.015$ \\
\hline & 97 & Chicken & $0.026 \pm 0.018$ \\
\hline & 98 & Fish & $0.068 \pm 0.051$ \\
\hline & 99 & Fresh meat & $0.042 \pm 0.004$ \\
\hline
\end{tabular}


Table 1. Cont.

\begin{tabular}{cccc}
\hline \multirow{3}{*}{ Fats and oils } & 100 & Eggs & $0.074 \pm 0.009$ \\
& 101 & Noor & $0.020 \pm 0.012$ \\
& 102 & Shams & $0.030 \pm 0.005$ \\
& 103 & Abu Zahra & $0.006 \pm 0.001$ \\
& 104 & Afia & $0.005 \pm 0.001$ \\
\hline
\end{tabular}

Considering the amount of food consumed, the major food sources of lead intake for Saudis were vegetables $(25.4 \%)$, cereals and cereal products $(24.2 \%)$, beverages $(9.7 \%)$, sweets $(8.2 \%)$, legumes $(7.4 \%)$, fruits $(5.4 \%)$, milk and milk products $(5.1 \%)$ and finally pickles $(1.1 \%)$, and the mean daily intake of lead is $24.57 \mu \mathrm{g} /$ person/day. The lead daily intake for each person was estimated by multiplying the mean intake of each food items by its mean lead content as shown in Table 2 .

Table 2. Lead daily intake in correlation with the questionnaire.

\begin{tabular}{lcccc}
\hline Kind of food & $\begin{array}{c}\text { Daily } \\
\text { consumption } \\
\text { (g/day) }\end{array}$ & $\begin{array}{c}\mathbf{P b} \text { Conc } \\
\mu \mathbf{g} / \mathbf{g}\end{array}$ & $\begin{array}{c}\text { Daily Pb intake } \boldsymbol{\mu g} / \\
\text { person/day }\end{array}$ & Contribution \% \\
\hline Vegetables & 254.49 & 0.025 & 6.247 & 25.4 \\
Fruits & 78.02 & 0.017 & 1.318 & 5.4 \\
Pickles & 10.39 & 0.03 & 0.261 & 1.1 \\
Legumes & 44.91 & 0.04 & 1.828 & 7.4 \\
Cereal and cereal product & 270.01 & 0.022 & 5.958 & 24.2 \\
Milk and milk products & 83.79 & 0.01 & 1.249 & 5.1 \\
Beverages & 66.71 & 0.04 & 2.387 & 9.7 \\
Sweets & 54.77 & 0.04 & 2.012 & 8.2 \\
Meat and meat products & 108.60 & 0.029 & 3.161 & 12.9 \\
Fats and oils & 10.00 & 0.02 & 0.153 & 0.6 \\
Daily lead intake $(\mu \mathrm{g} / \mathrm{person} /$ day) & & $\mathbf{2 4 . 5 7 4}$ & 100 \\
$\quad$ Daily lead intake $(\mu \mathrm{g} /$ Kg body wt/day) & & 0.351 & \\
Lead intake $(\mu \mathrm{g} /$ Kg body wt/week) & & 2.457 & \\
\hline
\end{tabular}

The results in Table 3 shows the comparison between the estimated daily lead intake for each person from the questionnaire with the calculated daily lead intake from the KSA food balance sheet according to the FAO [28]. As shown from the data in Table 2, the mean daily intake of lead is $24.57 \mu \mathrm{g} /$ persom/day. This value is similar to the estimated daily intake of lead according to the food balance sheet of KSA of the FAO [28] which was $22.74 \mu \mathrm{g} /$ person/day (Table 3).

Table 3. Lead daily intake in correlation with the KSA food balance given by the FAO.

\begin{tabular}{lccc}
\hline Food kind & $\begin{array}{c}\text { Pb Conc } \mu \mathbf{g} / \mathbf{g} \\
\text { food }\end{array}$ & $\begin{array}{c}\text { Daily consumption } \\
\text { of food }(\mathbf{g})\end{array}$ & $\begin{array}{c}\text { Daily Pb intake } \\
\boldsymbol{\mu g} / \mathbf{p e r s o n} / \mathbf{d a y}\end{array}$ \\
\hline Vegetables & 0.025 & 289.5 & 7.15 \\
Zucchini & 0.013 & 16.4 & 0.21 \\
Carrots & 0.027 & 0.26 & 0.01 \\
Potatoes & 0.013 & 47.6 & 0.63 \\
Tomatoes & 0.02 & 82.5 & 2.04 \\
\hline
\end{tabular}


Table 3. Cont.

\begin{tabular}{lccc}
\hline Dry dates & 0.02 & 74.7 & 1.33 \\
Cereal and cereal product & 0.022 & 332 & 7.33 \\
White cheese & 0.003 & 50 & 0.13 \\
Meat and meat products & 0.029 & 135 & 3.93 \\
Daily lead intake $(\mu \mathrm{g} /$ person/day) & & & $\mathbf{2 2 . 7 4}$ \\
Daily lead intake $(\mu \mathrm{g} / \mathrm{Kg}$ body Wt/day) & & & 0.32 \\
Lead intake $(\mu \mathrm{g} / \mathrm{Kg}$ body Wt/weak) & & & 2.27 \\
\hline
\end{tabular}

The data in Table 4 show the estimated intake of $\mathrm{Pb} /$ person/day. Lead daily intake ( $24.5 \mu \mathrm{g} /$ person/day) of Saudi subjects shows a higher value than that of the cities of Seoul and Tainan ( 21.5 and $19.5 \mu \mathrm{g} /$ person/day respectively) but considerably lower than that of the cities of Naning and Xian (32.3 and $26.1 \mu \mathrm{g} /$ person/day respectively). The lowest lead intake per day was recorded in Kualalumpour and Tokyo which were 7 and $9.3 \mu \mathrm{g} /$ person/day, respectively (Table 4).

Table 4. Comparison of the estimated $\mathrm{Pb}$ intake of population in various cities.

\begin{tabular}{lcc}
\hline City & Lead concentration in food $(\boldsymbol{\mu g} /$ day $)$ & References \\
\hline Riyadh & 24.5 & Our study \\
Bangkok & 15.1 & {$[64]$} \\
Kualalumpur & 7 & {$[64]$} \\
Manila & 11.3 & {$[64]$} \\
Tainan & 19.5 & {$[64]$} \\
Beijing & 23.9 & {$[64]$} \\
Jinan & 26 & {$[64]$} \\
Naning & 32.3 & {$[64]$} \\
Shanghai & 17.2 & {$[64]$} \\
Xian & 26.1 & {$[64]$} \\
Tokyo & 9.3 & {$[64]$} \\
Seoul & 21.5 & {$[64]$} \\
\hline
\end{tabular}

Ikeda et al 2000 [64]

\section{Discussion}

The factors affecting the concentration of lead in food, depends on the type of food, the methods of processing and storage. The food analysis indicated that sweets contain higher amounts of lead than other foods, followed by meat and meat product then by leafy vegetables, while the lowest lead contents were found in fruits and beverages. Processing or storing food in lead contaminated pots causes a significant lead elevation in food. Cooking with acidic foods (such as tomatoes, vinegar, and alcohol or soy source) in these pots is of special concern because their low $\mathrm{pH}$ enhances the leaching process [29] for this reason, we found that processed meat and canned legumes contains high amount of lead, as shown in Table 1.

The data in Table 1 shows that some sweets contain higher amounts of lead such as Snickers $(0.199 \mu \mathrm{g} / \mathrm{g})$, Triplex $(0.131 \mu \mathrm{g} / \mathrm{g})$, Twix $(0.092 \mu \mathrm{g} / \mathrm{g})$, Galaxy $(0.085 \mu \mathrm{g} / \mathrm{g})$ and Halvah $(0.08 \mu \mathrm{g} / \mathrm{g})$. Recent warnings issued by the U.S. Food and Drug Administration (FDA) and state health departments 
have increased concern about contamination in candy imported from Mexico [30,31]. The Centers for Disease Control (CDC) [32] reported that, based on routine blood lead screening, six California children suffered from lead toxicity after eating tamarind- and chili-flavored candy imported from Mexico. The FDA then found between $0.3 \mu \mathrm{g}$ to $0.4 \mu \mathrm{g}$ of lead per gram of candy. The California Department of Health Services independently found elevated lead levels in candy as well $(>0.5 \mu \mathrm{g}$ of lead per gram) [31]. It is believed that lead contamination may be introduced from ingredients during candy processing such as drying, storing, and grinding or that lead may leach in to the candy from tainted wrappers [33].

In the same respect, contamination of chocolate by lead is thought to occur because the majority of beans are grown in locations that still use leaded gasoline. Despite high per capita consumption of chocolate in the United States, there is paucity of data of lead concentration in chocolate products. The American Environment Safety Institute, an environmental advocacy group based in California, tested a variety of chocolate products and found that they contained $0.00157 \mu \mathrm{g}$ and $0.105 \mu \mathrm{g}$ lead per gram chocolate. The United State Department of Agriculture's (USDA) total diet study [34] found between 0.0 and $0.11 \mu \mathrm{g}$ lead per gram chocolate. Analysis of chocolate samples by our research group yielded similar results. Mean lead levels ranged from 0.04 to $0.093 \mu \mathrm{g}$ lead per gram chocolate except for Triplex and Snickers which had higher levels of lead $(0.131$ and $0199 \mu \mathrm{g} / \mathrm{g}$ ) respectively (Table 1$)$.

The Codex Alimentarius, global food standards developed by FAO and WHO, limits the lead content of coca powder or beans to $1 \mu \mathrm{g}$ of lead per gram product [35]. Analysis of a variety of chocolate products from various global location completed by a Swiss group in 2002, found that the lead content of these items ranged from $0.0011 \mu \mathrm{g}$ to $0.769 \mu \mathrm{g} / \mathrm{g}$, below the international standards [36]; this, coupled with research suggesting that only $5 \%$ to $10 \%$ of lead contained in cocoa is bio- available to the body [37], indicates that there is limited risk of lead toxicity due to to regular consumption of chocolate products.

The maximum lead limit for human health has been established for edible parts of crops as $0.3 \mu \mathrm{g} / \mathrm{g}$ by WHO but this limit in china is $0.2 \mu \mathrm{g} / \mathrm{g}$. Data in table (1) shows that lead concentration in vegetables, fruits, and cereal products are in the range of 0.002 to $0.192 \mu \mathrm{g} / \mathrm{g}$. The lead levels in these products are below the maximum WHO or china limits and comparable to those observed in other studies [38]. They attributed the lower levels of lead to the successful phasing out of leaded gasoline in European countries when leaded fuel is burned, it emit very fine particles of lead into the air, where they may settle on vegetables as they are vended along the street and next to bays high ways. Some of particles settle on soil where they later contaminate the food when the dust is blown by wind [39]. Other investigations have also reported high levels of lead content in vegetables sampled near major high ways [40]. Perhaps, not surprisingly, there is good correlation between average traffic counts and average soil and plant lead content of sites close to the road side. An inverse relationship between distance from the road and lead content has been observed in various soil and vegetables [40]. In Japan, Maramatsa, et al. [41] found lead concentrations of 2.3 and $2.4 \mu \mathrm{g} / \mathrm{g}$ in spinach and $1.2 \mu \mathrm{g} / \mathrm{g}$ in cabbage.

Yang et al. [42] reported that cereal in China had lead levels of $0.06 \mu \mathrm{g} / \mathrm{g}$. In Denmark the national food agency establishes lead levels of $0.03 \mu \mathrm{g} / \mathrm{g}$ in cereals $[43,44]$. Another study by Urieta et al. [45] found mean lead levels of $0.02 \mu \mathrm{g} / \mathrm{g}$ in cereal from Spain. In the United Kingdom, Ysart [46] reported mean lead levels of $0.02 \mu \mathrm{g} / \mathrm{g}$ in cereal products. In Poland, Krelowska-Kula [47] found lead levels of 
$0.07 \mu \mathrm{g} / \mathrm{g}$ in cereal. In Japan, Muramatsu et al., [41], established lead concentrations of $0.05 \mu \mathrm{g} / \mathrm{g}$ in wheat and rice. While in this study the lead levels in cereal and cereal products ranged from $0.008 \mu \mathrm{g} / \mathrm{g}$ in white bread to $0.047 \mu \mathrm{g} / \mathrm{g}$ in pasta. The lead levels in rice ranged from $0.02 \mu \mathrm{g} / \mathrm{g}$ in Abu Sion rice to $0.032 \mu \mathrm{g} / \mathrm{g}$ in Karose Snowhite Rice.

The maximum acceptable limit of lead levels in fish is $0.2 \mu \mathrm{g} / \mathrm{g}$ according to Turkish and EU limits $[48,49]$. In this study the lead levels in meat and meat products ranged from $0.013 \mu \mathrm{g} / \mathrm{g}$ in Cooked fish (Incheon Rural Slides) to $0.074 \mu \mathrm{g} / \mathrm{g}$ in eggs, whereas the lead level in cooked sardines was $0.063 \mu \mathrm{g} / \mathrm{g}$. Sireli et al. [50] reported that the concentration of lead in fish samples varied from 0.001 to $0.791 \mu \mathrm{g} / \mathrm{g}$, with a mean of $0.177 \mu \mathrm{g} / \mathrm{g}$. Current Turkish legislation specifies the maximum lead limit in fish meat as $0.2 \mu \mathrm{g} / \mathrm{g}$ [48], which are in line with the corresponding EU regulations [49]. Eboh et al., [51] reported lead in the muscle, gills and liver tissues of fish at a range of $0.001-0.002 \mu \mathrm{g} / \mathrm{g}$; on the other hand, the mean concentrations of lead (4.27-6.12 $\mu \mathrm{g} / \mathrm{g})$ reported by Canli and Atli [52] in muscle tissues of six different fish species are higher than our results. The concentration of lead in canned tuna samples were found to be $0.0162-0.0726 \mu \mathrm{g} / \mathrm{g}$, with a mean of $0.0366 \mu \mathrm{g} / \mathrm{g}$ [53], which are in line with our results.

In this study the concentration of lead in the fruits drinks ranged from 0.01 to $0.053 \mu \mathrm{g} / \mathrm{g}$ and followed the order lemon $>$ fruit $>$ strawberry $>$ orange and carrot $>$ apple $>$ orange. These concentrations are below the guideline values for lead in juice drinks reported by Chukwujidu et al., [54], who found that lead concentration in juice drinks ranged from 0.06 to $1.93 \mu \mathrm{g} / \mathrm{g}$. The major source of lead in canned fruit drinks is the leaching of lead from the canning process. Adraiano [55] reported lead levels of $0.01 \mu \mathrm{g} / \mathrm{g}$ for beverage drinks in Canadas. Paolo and Maurizio [56] reported mean lead levels of $0.38 \mu \mathrm{g} / \mathrm{g}$ for fruits drinks, while Contrer Aslopez et al., [57] reported $0.15 \mu \mathrm{g} / \mathrm{g}$ lead in fruit drinks in Spain. The mean levels of lead in the various brands were below the level reported by these authors except for those reported in Canada by Adraiano [56].

As shown in Table 1 the lead levels in milk and milk products ranged from 0.018 to $0.055 \mu \mathrm{g} / \mathrm{g}$. These levels are in line with the lead levels in raw milk in samples from various factories in Iran $(0.01-0.023 \mu \mathrm{g} / \mathrm{g})$, whereas the milk lead levels in Poland are very high (1.16-3.74 $\mu \mathrm{g} / \mathrm{g})$, as reported by Baranowska et al. [58]. In China the lead concentration levels in milk-based products increased over a period of 10 years [59]. However, although levels of lead in milk seem to have risen slightly in other countries over the past 20-30 years, there is no evidence of any real increase in dietary lead during recent decades. Recent comparisons of lead in food in North-America with those obtained over 20 years earlier also don't suggest any increase in lead intake by man from this source [60].

One of the probable reasons for the increase in other countries may be the wide use of leaded gasoline during recent decades [61]. Another important source of lead contamination in food and feed is water, especially in more contaminated areas [62].

The lead daily intake, extracted from questionnaire daily food consumption was $24.5 \mu \mathrm{g} /$ person/day. This value is slightly higher than the daily lead intake calculated from the food balance of KSA given by the FAO, which is $22.7 \mu \mathrm{g} /$ person/day, Tables 2 and 3. The total lead exposure in European diet (European diet provides the maximum potential for weekly intake of lead through food) would be $4.63 \mu \mathrm{g}$ of lead per kg body weight [63] for an average person of $60 \mathrm{~kg}$ body weight and the mean weekly intake is $277.8 \mu \mathrm{g}$, which would be somewhat less than the PTWI of 1,500 $\mu \mathrm{g}$ for lead [22]. However, the lead exposure, especially for infant consumption, should be 
minimized as much as possible. In this study the weekly intake of lead through food estimated as 171.5 $\mu \mathrm{g} / \mathrm{person} /$ week, a value that is much lower than that previously mentioned by JECFA [22].

The data in Table 4 shows that the estimated lead daily intake of the Riyadh population from food ( $24.5 \mu \mathrm{g} /$ person/day) is higher than that of the populations of Kuala Lumpur ( $7 \mu \mathrm{g} / \mathrm{person} /$ day), Tokyo (9.3 $\mu \mathrm{g} /$ person/day), Shanghai (17.2 $\mu \mathrm{g} /$ person/day), Beijing $(23.9 \mu \mathrm{g} /$ person/day) and lower than that of Jinan $(26 \mu \mathrm{g} /$ person/day), Xian $(26.1 \mu \mathrm{g} /$ person/day) and Naning (32.3 $\mu \mathrm{g} /$ person/day) [64].

\section{Experimental}

\subsection{Sampling}

Samples from local foodstuffs from Saudi Arabia (KSA) were collected during May 2009. Three kilograms of each fresh sample were collected from different market in Riyadh city in polyethylene containers to avoid contamination. The groups of foodstuffs studied are shown in Table 5.

Table 5. Food samples, name and categories from Riyadh city markets.

\begin{tabular}{|c|c|}
\hline Food groups & Samples \\
\hline Vegetables & $\begin{array}{l}\text { Cucumber, zucchini, green peas, carrots, potatoes, eggplant, green peppers, okra, } \\
\text { thyme, green hot pepper, sweet potato, taro, onion, garlic, canned taro, canned } \\
\text { green peas, canned carrots, canned okra, canned spinach, canned potato, canned } \\
\text { jews mallow, mallow, purslane, radish, dill, spinach, lettuce, round leafy lettuce, } \\
\text { mint, coriander, cauliflower, watercress, cabbage and green onions }\end{array}$ \\
\hline Fruits & $\begin{array}{l}\text { Tomatoes, banana, strawberry, orange, pears, lemon, apple, canned strawberry } \\
\text { and dried dates }\end{array}$ \\
\hline Pick & Pickled cucumber and pickled turnip \\
\hline Legl & $\begin{array}{l}\text { Green kidney bean, canned green kidney beans, canned kidney beans, canned } \\
\text { beans, canned beans, beans, canned peas and cowpeas }\end{array}$ \\
\hline $\begin{array}{l}\text { Cereal an } \\
\text { products }\end{array}$ & $\begin{array}{l}\text { Pasta, rice (Karos Snowhite), rice (Abu Sion), bread, white bread, biscuits } \\
\text { (Tyoshob), biscuits (Tyoshob strawberry), tea biscuits, biscuits, (Loucker } \\
\text { Napolitaner) }\end{array}$ \\
\hline $\begin{array}{l}\text { Milk and } \\
\text { milk Products }\end{array}$ & $\begin{array}{l}\text { Fresh milk, Danette banana-flavored milk, Danette strawberry-flavored milk, } \\
\text { Yogurt, cheese, ice cream (plastic tray), ice cream (paper package), vanilla ice } \\
\text { cream (paper package) }\end{array}$ \\
\hline Beverages & $\begin{array}{l}\text { Orange and carrot juice, apple juice, fruit juice, orange juice, lemon juice, } \\
\text { strawberry juice, Lipton tea packages, Lipton Tea, coffee }\end{array}$ \\
\hline Sweets & $\begin{array}{l}\text { Bounty, Galaxy, Snickers, Vip, Albeni, Triplex, Towers gold, Twix, Rush } \\
\text { Halvah }\end{array}$ \\
\hline $\begin{array}{l}\text { Meat and meat } \\
\text { products }\end{array}$ & $\begin{array}{l}\text { Sardines Haakon hot, light meat tuna (Eldiafa), light meat tuna (C Harvest), } \\
\text { Cooked fish (Luncheon Rural Slides), light meat tuna (IFFCO), light meat tuna } \\
\text { (California) } \\
\text { sardines cooked (Milo), chicken, fish, fresh meat and eggs. }\end{array}$ \\
\hline Fats and Oils & Shams, Noor, Abu Zahra and Afia \\
\hline
\end{tabular}

\subsection{Sample preparation}

For processed foods, those brands commanding a high share of the domestic market were purchased. Three samples for each food item were purchased in May 2009. The samples were dried at $100{ }^{\circ} \mathrm{C}$ till constant weight and ground with special mills, with provisions to prevent contamination (grinding 
parts made of aluminum and titanium), into a homogenous matter. A sample (150 g) was taken and stored in air-tight polyethylene bottles at $18{ }^{\circ} \mathrm{C}$ until analysis, as described $[65,66]$.

\subsection{Chemical analysis}

High purity chemicals were used in all tests. All reagents met the specifications of the Committee on Analytical Reagents of the American Chemical Society, and included: nitric acid (ultra pure $\mathrm{HNO}_{3}$, 70\%) from Wenlab (UK); hydrochloric acid (36\%), sulfuric acid, hydrofluoric acid and perchloric acid from BDH Laboratory Supplies (UK); hydrogen peroxide from Petrochem (UK) and reagent water (high purity, $18 \mathrm{M} \Omega$ ). Food samples was wet digested using heating $\left(150^{\circ} \mathrm{C}\right)$ on a hot plate $(\mathrm{PC}-351$, Corning Incorporated Life Sciences, Lowell, MA, USA) using different acids for each food category according to the methods mentioned in [54,67-69]. The same pretreatment procedure was repeated until the darkness of solution disappeared. After cooling, the digested solution was diluted with deionized water and transferred to a $50-\mathrm{mL}$ volumetric flask. The diluted solution was filtered through a filter paper into a polyethylene tube $(50 \mathrm{~mL})$, then the lead concentration in the digested samples was determined in ppb using ICPAES [Thermo Scientific ICAP 6500 ICP-AES with SIK (standard introduction kit); glass concentric nebulizer /cyclonic spray chamber, USA] [70]. A recovery study of the analytical procedure was carried out by spiking and homogenizing several already analyzed samples with varied amounts of standard solutions of lead. The spiked samples were processed for the analysis by same procedure as described above. Average recovery obtained was $97.55 \pm 1.6$.

\subsection{Estimation of dietary lead intake}

The lead intake per person per day was estimated from the KSA food balance sheet given by the FAO and from a questionnaire which was distributed among three hundred families in Riyadh city. The answers on the quantities of food they consumed independentally of financial situation was collected and the mean values were calculated by multiplying the amount of each food categories consumed by the mean lead concentration in each categories, as shown in Table 6 .

Table 6. Example for lead daily intake calculation from food samples.

\begin{tabular}{|c|c|c|c|}
\hline Item & Consumption g/day & Mean lead concentration $(\mu \mathrm{g} / \mathrm{g})$ & Daily intake \\
\hline Vegetables & 200 & 0.025 & 5 \\
\hline Meat and meat products & 100 & 0.029 & 2.9 \\
\hline Fruits & 150 & 0.017 & 2.55 \\
\hline Legumes & 100 & 0.04 & 4 \\
\hline Cereal and cereal products & 200 & 0.022 & 4.4 \\
\hline Beverage & 100 & 0.04 & 4 \\
\hline Sweets & 70 & 0.04 & 2.8 \\
\hline \multicolumn{3}{|c|}{ Daily lead intake ug/person/day } & 25.65 \\
\hline
\end{tabular}

Assuming that body weight is $70 \mathrm{~kg}$ 


\subsection{Statistical analysis}

The obtained results were analyzed using the SPSS program (version 17).

\section{Conclusions}

By analyzing the lead content in representative food items in Riyadh city, the capital of Saudi Arabia, a lead database was made on a limited scale for 104 food items. The food balance sheet of KSA provided by the FAO was analyzed to select food for analysis. Vegetables, cereals and cereal products, beverages and sweets turned out to be the major source of lead for Saudis. The main daily intake of lead is $24.57 \mu \mathrm{g} /$ person/day, as calculated from questionnaire data and is $22.7 \mu \mathrm{g} / \mathrm{person} /$ day as calculated from the KSA food balance sheet according to the FAO.

\section{Acknowledgements}

This work was supported by the College of Science Research Center, King Saud University, project number 1401112.

\section{References}

1. Centers for Disease Control (CDC). Preventing lead poisoning in young children: a statement by the Centers for Disease Control; US Dept. of Health and Human Services: Atlanta, GA, 1991.

2. Mary, E.F.; Kimberly, A.G.; Helen, J.B. Lead levels of edibles grown in contaminated residential soils: A field survey. Sci. Total Environ. 2004, 2-3, 245-257.

3. Sattar, A.; Wahid, M.; Durrani, S.K. Concentration of selected heavy metals in spices, dry fruits and plant nuts. Plant Foods Hum. Nutri. 1989, 39, 279-286.

4. Gilbert, J. Analysis of Food Contamination; Elsevier App. Sci.: London, UK, 1984; pp. 1-66.

5. Husain, A.; Baroon, Z.; Al-Khalafawi, S.; Al-Ati, T.; Sawaya, W. Heavy metals in fruits and vegetables grown in Kuwait during the oil well fires. Arab. Gulf J. Sci. Res. 1995, 13, 535-542.

6. Ozores, H.M.; Hanlon, E.; Bryan, H.; Schaffer, B. Cadmium, copper, lead, nickel and zinc concentrations in tomato and squash grown in MSW compost-amended calcareous soil. Compost. Sci. Utiliz. 1997, 5, 40-45.

7. Geert, E.; Loon, W.J.; Kars, T. Heavy metals in vegtables grown in the Netherlands and in domestic and imported fruits. Z. Lebensm. Unters. Forsch. 1989, 190, 34-39.

8. Tsoumbaris, P.; Tsoukali, P.H. Heavy metals in common foodstuff: Quantitative analysis. Bull. Environ. Contamin. Toxicol. 1994, 53, 61-66.

9. Rahlenbeck, S.I.; Burberg, A.; Zimmermann, R.D. Lead and cadmium in Ethiopian vegetables. Bull. Environ. Contam. Toxicol. 1999, 62, 30-33.

10. Sterrett, S.B.; Chaney, R.L.; Hirsch, C.E.; Mielke, H.W. Influence of amendments on yield and heavy metal accumulation of lettuce grown in urban garden soils. Envir. Geochem. Health 1996, $18,135-142$.

11. Chen, J.; Gao, J. The Chinese Total Diet Study in 1990. Part I. Chemical Contaminants. J. AOAC Intern. 1993, 76, 1193-1205. 
12. Food Standard Agency (FSA) of UK. Total Diet Study of 12 Elements- Aluminium, Arsenic, Cadmium, Chromium, Copper, Lead, Manganese, Mercury, Nickel, Selenium, Tin and Zinc; Food Surveillance Information Sheet No. 48/04. FSA: London, UK, 2004; Available from: http://www.food.gov.uk/multimedia/pdfs/fsismetals.pdf/, accessed on 27 November 2007.

13. Watanabe, T.; Shimbo, S.; Moon, C.S.; Zhang, Z.W.; Ikeda, M. Cadmium contents in rice samples available from various areas in the world. Sci. Total Environ. 1996, 184, 191-196.

14. Burger, K.F.; Gaines, C.; Boring, W.L.; Stephens, J.S.; Dixon. Metal levels in fish from the Savannah River: Potential hazards to fish and other receptors. Environ. Res. 2002, 89, 85-97.

15. Marijic, V.F.; Raspor, B. Metal exposure assessment in native fish, Mullus barbatus L., from the Eastern Adriatic Sea. Toxicol. Lett. 2007, 168, 292-301.

16. Tuzen, M.; Soylak, M. Determination of trace metals in canned fish marketed in Turkey. Food Chem. 2007, 10, 1378-1382.

17. Srogi, K. Assessment of selected heavy metal contents in medicinal plants, tea leaves and chocolate using atomic absorption spectrometry. Acta Toxicol. 2006a, 14, 117-128.

18. Karadjova, I.; Girousi, S.; Illiadou, E.; Stratis, I. Determination of $\mathrm{Cd}, \mathrm{Co}, \mathrm{Cr}, \mathrm{Cu}, \mathrm{Fe}, \mathrm{Ni}$ and $\mathrm{Pb}$ in milk, cheese and chocolate. Microchem. Acta 2000, 134, 185-191.

19. Rankin, C.W.; Nriagu, J.O.; Aggarwal, J.K.; Arowolo, T.A.; Adebayo, K.; Flegal, A.R. Lead contamination in cocoa and cocoa products: Isotopic evidence of global contamination. Environ. Health Persp. 2005, 113, 1344-1348.

20. WHO. Trace Elements in Human Nutrition and Health; World Health Organization: Geneva, Switzerland, 1995.

21. CAC/FAO. Situation Analysis of Children and women in Kenya. Food Standards Programme. Codex Committee on Food Additives and Contaminants. 32nd Session. Draft Maximum Levels of Lead; GoK/UNICEF. UNICEF/GOK: Nairobi, Kenya, 1999.

22. JECFA. Safety Evaluation of Certain Food Additives and Contaminants. 44 IPCS - International Programme on Chemical Safety Contaminants, 2000, http://www.inchem.org/documents/jecfa/ jecmono/v44jeeI2.htm/, accessed on 21 June 2000.

23. Celik, U.; Oehlenschlager, J. Determination of zinc and copper in fish samples collected from Northeast Atlantic by DPSAV. Food Chem. 2004, 87, 343-347.

24. Tuzen, M. Determination of heavy metals in fish samples of the middle Black Sea (Turkey) by graphite furnace atomic absorption spectrometry, Food Chem. 2003, 80, 119-123.

25. Voegborlo, R.B.; El-Methnani, A.M.; Abedin, M.Z. Mercury, cadmium and lead content of canned tuna fish. Food Chem. 1999, 67, 341-345.

26. FAO/WHO. Code of Practice for the Prevention and Reduction of Lead Contamination in Foods (CAC/RCP 56-2004). FAO/WHO: Rome, Italy, 2004, pp. 1-5. Available from: http://www.codex alimentarius.net/download/standards/10099/CXC_056_2004e.pdf/.

27. ATDR, Agency for Toxic Substances and Disease Registry. The Nature and Extent of Lead Poisoning in Children in the United States; US Department of Health and Human Services, Public Health Service: Atlanta, GA, USA, 1988.

28. Al-ahmary, K.M. Selenium content in selected foods from the Saudi Arabia market and estimation of the daily intake. Arabian J. Chem. 2009, 2, 95-99. 
29. U.S. Department of Homeland Security (U.S. DHS). Emergency Support Function, Logistics Management and Resource Support Annex; DHS: Washington, DC, USA, 2008b.

30. FDA, Hazard Analysis and Critical Control Point (HAACP); Procedures for the Safe and Sanitary Processing and Importing of Juice; Final Rule, Federal Register 2001, 66, 6137-6202.

31. Lead in Candy, Laboratory Results; DHS: Sacramento, CA, USA, 2005. Available online: www.dhs.ca.gov/fdb/ PDF/ 05\%20candy\%20results\%20for\%20web\%20final.pdf (accessed on 29 August 2010).

32. Lead in Candy: Questions and Answers; CDC: Atlanta, GA, USA, 2005. Available online: www.cdc.gov/nceh/lead/ faq/candy.htm/, accessed on 29 August 2010.

33. Fuortes, L.; Bauer, E. Lead contamination of imported candy wrappers. Vet. Hum. Toxicol. 2000, 42, 41-42.

34. Total Diet Study Statistics on Element Results; FDA: Washington; DC, USA. 2004b, pp. 58-68. Available online: www.cfsan.fda.gov/ acrobat/ tds1byel.pdf/, accessed on 5 January 2005.

35. United Nations' Food and Agriculture Organization and World Health Organization (FAO/WHO). Codex Alimentarius. Codex Standard for Chocolate 87; Available online: www.codexalimentarius.net/web/standard_list.jsp/.

36. Mounicou, S.; Szpunar, J.; Andre, D. Concentrations and bioavailability of cadmium and lead in cocoa powder and related products. Food Addit. Contam. 2003, 20, 343-352.

37. Mounicou, S.; Szpunar, J.; Andrey, D. Development of a sequential enzymolysis approach for the evaluation of the bioaccessibility of $\mathrm{Cd}$ and $\mathrm{Pb}$ from cocoa. Analyst 2002, 127, 1638-1641.

38. Benko, V.; Cikrt, M.; Lener, J. Toxic Metals in the Environment; Grada Publishing: Prague, Czech Republic, 1995; p. 282.

39. UNEP. Global Environment Outlook; Earth Scan Publications Ltd.: London, UK, 2000; pp. 132-133.

40. Tyroller, H.A. Epidemiology of hypertension as a public health problem: An Overview as background for evaluation of lead blood pressure relationships. Environ. Health Persp. 1988, 78, 3-7.

41. Muramatsu, Y.; Sumiya, M.; Yanasigawa, K.; Ohmomo, Y. Trace and Toxic elements in foodstuffs. In: Nuclear Techniques for Toxic Elements in Foodstuffs. Report on an IAEA Coordinated Research Programme. Vienna 1994, 156-172.

42. Yang, H.F.; Luo, X.Y.; Shen, W.; Zhou, Z.F.; Jin, C.Y.; Yu, F.; Liang, C.S. National Food Contamination Monitoring Programs- Levels of Mercury,lead and cadmium in Chinese foods. Biomed. Environ. Sci. 1994, 7, 362-368.

43. Food Monitoring 1988-1992; National Food Agency of Denmark: Copenhagen, Denmark, 1992.

44. Andersen, N.L.; Fragt, S.; Groth, M.V.; Hatkopp, H.B.; Moller, A.; Ovesen, L.; Warming, D.L. Dietary Habits in Denmark. Main Results; Publication No. 235. National Food Agency: Copenhagen, Denmark, 1996.

45. Urieta, I.; Jalon, M.; Eguileor, I. Food Surveillance and the Basque country Spain, Estimation of the dietary intake of organochlorine pesticides, heavy metals, arsenic, aflatoxin M1, iron and zinc through the total diet study. Food Addit. Cont. 1996, 13, 29-52.

46. Ysart G. Dietary exposure estimates of 300 elements from UK total diet study. Food Add. Cont. 1994, 9, 391-403. 
47. Krelowska, K.M. Metal contents in certain food products. Die Nehrung 1991, 35, 363-367.

48. Anonymous. Establishment of Maximum Residue Limits of Certain Contaminants in Foods; Turkish Food Codex No. 2002/63; (Türk Gıda Kodeksi, Gıda maddelerinde belirli bulaşanların maksimum seviyelerinin belirlenmesi hakkında tebliğ No: 2002/63).

49. Anonymous.Commission Regulation (EC) No: 78/2005 of 16 January 2005 amending Regulation EC No: 466/2001 as regards heavy metals. Offic. J. Eur. Union 2005, 43-45.

50. Şireli, U.T.; Göncüoğlu, M.; Yildırım, Y.; Gücükoğlu, A. Çakmak, Ö. Assessment of Heavy Metals (Cadmium and Lead) in Vacuum Packaged Smoked Fish Species (Mackerel, Salmo salar and Oncorhynhus mykiss) Marketed in Ankara (Turkey)*. EU. J. Fish. Aquat. Sci. 2006, 23, 353-356.

51. Eboh, L.; Mepba, H.D.; Ekpo, M.B. Heavy metal contaminants and processing effects on the composition, storage stability and fatty acid profiles of five common commercially available fish species in Oron Local Government, Nigeria. Food Chem. 2006, 97, 490-497.

52. Canli, M.; Atli, G. The relationships between heavy metal ( $\mathrm{Cd}, \mathrm{Cr}, \mathrm{Cu}, \mathrm{Fe}, \mathrm{Pb}, \mathrm{Zn})$ levels and the size of six Mediterranean fish species. Environ. Pollut. 2005, 121, 129-136.

53. Khansari, F.E.; Khansari, M.G.; Abdollahi, M. Heavy metals content of canned tuna fish. Food Chem. 2005, 93, 293-296.

54. Chukwujindu, M.A.; Iwegbue, S.O.; Nwozo, E.K.; Ossai, Nwajei, G.E. Heavy metal composition of some imported canned fruit drinks in Nigeria. Am. J. Food Technol. 2008, 3, 220-223.

55. Adraiano, D. Trace Metals in the Terrestrial Environmen, 1st Ed.; Spiegler, V.: New York, NY, USA, 1984.

56. Paolo, B.; Maurizio, C. Simultaneous determination of copper, lead and zinc in wine by differential pulse polarography. Analyst 1978, 107, 271-280.

57. Contrer Aslopez, A.; Llanaza, C.A.; Santamaria, D.P. Metal content of apple juice for cider in Asturia (Spain). Afinidad 1987, 44, 501-503.

58. Baranowska, I.; Barchanska, H.; Pyrsz, A. Distribution of pesticides and heavy metals in trophc chain. Chemosphere 2005, 60, 1590-1599.

59. Wang, M. Study on food contaminants monitoring in China during 2000-2001. Wei Sheng Yan Jiu 2003, 32, 322-326.

60. World Health Organization. Evaluation of Mercury, Lead, Cadmium and the Food Additives Amaranth, Diethylpyrocarbonate and Octyl Gallate; WHO Food Addit. Series 1972; No. 4. http://www.inchem.org/ documents/jecfa/jecmono/v004je03.htm, (accessed on 12 April 1972).

61. Rizov, M. Control of food and agro product contamination in Bulgaria. Arh. Hig. Rada. Toksikol. 2001, 52, 177-180.

62. Codex Alimentarius Commission. Report of the 35th Session of the Codex Committee on Food Additives and Contaminants, Arusha, Tanzania, 2003. http://www.codexalimentarius.net/ download/report/47/ A10312ae.pdf/, accessed on 5 July 2003)

63. GEMS/Food Regional Diets. Prepared by the Global Environment Monitoring System/Food Contamination Monitoring and Assessment Programme (GEMS/Food) 2003. http://www.who.int/ foodsafety/chem/en/gems_regional_diet.pdf/, accessed on 8 November 2004. 
64. Ikedaa, U.M.; Zuo, W.Z.; Shinichiro, S.T.; Watanabec, Haruo, N.; Chan, S.M.; Naoko, M.-I.; Kae, H. Urban population exposure to lead and cadmium in east and south-east Asia. Sci. Total Environ. 2000, 249, 373-384.

65. Baytak, S.; Türker, A.R. Determination of lead and nickel in environmental samples by flame atomic absorption spectrometry after column solid-phase extraction on Ambersorb-572 with EDTA, J. Hazard. Mat. 2006, 129, 130-136.

66. Oymak, T; Tokalığlu, S.; Yılmaz, V.; Kartal, S.; Aydın, D. Determination of lead and cadmium in food samples by the coprecipitation method. Food Chem. 2009, 113, 1314-1317

67. Acar, O. Determination of cadmium and lead in biological samples by Zeeman ETAAS using various chemical modifiers. Talanta 2001, 55, 613-622.

68. Ramesh, A.; Devi, B.A.; Hasewaga, H.; Maki, T.; Ueda, K. Nanometer-sized alumina coated with chromotropic acid as solid phase metal extractant from environmental samples and determination by inductively coupled plasma atomic emission spectrometry. Microchem. J. 2007, 86, 124-130.

69. Edem, C.A.; Grace, I.; Vincent, O.; Rebbeca, E.; Matilda, O. A Comparative Evaluation of Heavy Metals in Commercial Wheat Flours Sold in Calabar-Nigeria. Pak. J. Nutri. 2009, 8, 585-587.

70. Henk, J.W. Determination of Elements by ICP-AES and ICP-MS; National Institute of Public Health and the Environment (RIVM): Bilthoven, The Netherlands, 2003.

Sample Availability: Samples of the compounds are available from the.

(C) 2010 by the authors; licensee MDPI, Basel, Switzerland. This article is an open access article distributed under the terms and conditions of the Creative Commons Attribution license (http://creativecommons.org/licenses/by/3.0/). 